\title{
Importance of Investment Climates for Inflows of Foreign Direct Investment in Developing Countries
}

\author{
Dr. Nihal Bayraktar \\ Associate Professor of Economics, Pennsylvania State University-Harrisburg
}

Received: October 26, 2014 Accepted: November 16, 2014

doi:10.5296/ber.v5i1.6762 URL: http://dx.doi.org/10.5296/ber.v5i1.6762

\begin{abstract}
The changing direction of foreign direct investment towards developing countries has been attracting more attention in recent literature. As one possible source of the changing direction of FDI, the relationship between FDI inflows and some indicators of business friendliness (investment climate) of countries is investigated in this paper. The study covers the years from 2004 to 2013 and mainly focuses on developing countries. The results show that countries with better records of doing business tend to receive more FDI inflows. Improvements in the selected ease of doing business indicators, such as starting a business, protecting investors, and easiness of international trade, have a significant explanatory power in determining higher FDI flows to developing countries.
\end{abstract}

Keywords: Foreign Direct Investment, Doing Business Indicators, Developing countries, Investment Climate

JEL Codes: F21, F23, F41

\section{Introduction}

After the financial and economic crisis of 2008 and 2009, capital funds have started to flow towards developing countries more intensively, given the fact that returns on many investment options have been relatively higher in these countries. The share of capital flows towards developing countries has been historically high during this crisis period in the world. Such a large amount of capital inflows towards developing countries have caused enormous concerns for their macroeconomic and financial stability. These burdens have been even more valid in countries with relatively free financial markets, where capital can flow in and out without many restrictions. With such credible concerns, most countries have started to follow capital controls and/or macro prudential regulations to minimize the negative impacts of capital inflows on their economies and financial markets. ${ }^{1}$ Their objectives with such controls and regulations

${ }^{1}$ See, for example, Alfaro, Chari, and Kanczuk (2014), Blanchard, Dell' Ariccia, and Mauro (2010), 
have been reducing the volume of capital flows; reducing real exchange rate pressures; altering the composition of capital flows towards longer-term flows; and allowing for a relatively independent monetary policy.

Despite these major concerns and precautions, many economists agree that not all capital inflows are bad for economies. Short-term capital flows are considered the most dangerous ones because such inflows can leave the country easily in a short period of time (Blanchard, Ostry, Gosh, and Chamon, 2014). On the other hand, concerns on longer-term capital inflows, especially in the form of foreign direct investment (FDI), have been much more limited and such inflows have been considered most useful for developing economies. We can show China as an example (Resminia, Siedschlag, 2013; Ostry, Ghosh, Chamon, and Qureshi, 2011; Voss, Hinrich, Marc Fetscherin, and Philippe Gugler, 2010). China does not have free capital markets and they impose strict restrictions on foreign capital inflows. But, restrictions on foreign direct investment towards this country have been limited because the policymakers in the country have truly believed that this form of capital flows benefit them most.

It can be said that most countries have treated inflows of foreign direct investment differently when compared to the way they have treated other capital inflows. While imposing restrictions on other types of capital inflows, policymakers have tried to take necessary actions to increase foreign direct investment. One big reason for such distinction among capital flows is that inflows of foreign direct investment have been considered as an important source of growth, improvement in technology and production efficiency. The existence of such positive expected effects of FDI inflows has led to extensive literature on these capital flows. ${ }^{2}$ The changing direction of FDI towards developing countries from developed ones has started to attract even more attention in this literature. ${ }^{3}$

Given obvious benefits of FDI, one important question is what determines FDI and what type of country specific features can attract more FDI. In the literature, different factors are listed as possible determinants of FDI such as returns to investment, natural resources endowment, trade openness, financial openness, the size of countries, labor costs, level of human capital, macroeconomic and political determinants, taxes, as well as business friendliness (investment climate) in recipient countries. ${ }^{4}$ Especially the last set of factors is expected to be significant

Davis and Presno (2014), Magud, Reinhart, and Rogoff (2011), Medina and Roldos (2014), Ostry, Ghosh, Habermeier, Chamon, Qureshi, and Reinhardt (2010).

${ }^{2}$ See, for example, De Gregorio (1992), Olivia and Rivera-Batiz (2002), and Harris (2003), Kemme, Nikolsko - Rzhevskyy, and Mukherjee (2014).

${ }^{3}$ For example, Alfaro, Chanda, Kalemli-Ozcan, and Sayek (2010) show that a rise in the share of foreign direct investment leads to higher additional economic growth in financially developed economies relative to financially under-developed ones. Blonigen and Piger (2011) present that traditional gravity variables, cultural distance factors, parent-country per capita GDP, relative labor endowments, and regional trade agreements play an important role in determining foreign direct investment. They find that multilateral trade openness, host country business costs, host-country infrastructure, and host-country institutions are less important in determining FDI. Debaera, Lee, and Lee (2010) state that the impacts of outward investment differ by the level of development of the destination country of foreign direct investment. See also Kinoshita (2012), Alfaro and Chen (2010).

${ }^{4}$ Borensztein et al. (1995), Baliamoune-Lutz (2004), Sekkat et al. (2007), Adams (2009), Kinda (2009), Herzer (2011), and An (2012). 
determinants of FDI. After all, foreign direct investment means that foreign investors are opening a new business or operating an existing business in a foreign country. As indicated by the World Bank, "investment climate helps governments implement business reform, encourage private sector development and generate investment." Thus, the level of indicators of investment climate in a country must be important for FDI decisions of foreign investors.

In light of this argument the aim of this paper is to evaluate whether developing countries with improving indicators of investment climate can attract more FDI inflows; and if so, which indicators can be more significant in determining such. The focus of this paper is on developing countries. One reason for this preference is that the share of developing countries in the world's FDI inflows has been increasing dramatically in recent years, especially after the financial and economic crisis of 2008 and 2009. The second reason is that the values of investment climate indicators are already very high in developed countries and we do not observe many fluctuations in their values, especially in the short term; thus it is harder to link improvements in indicators to FDI inflows in developed countries.

More specifically, in this paper, the relationship between foreign direct investment and "ease of doing business" indicators (possible determinants of the investment climate of countries) is investigated as one possible source of the changing direction of FDI towards developing countries. ${ }^{5}$ The data source for "ease of doing business" indicators is the World Bank's Doing Business Database. The study covers the years from 2004 to 2013. Because the paper includes the period right before the economic and financial global crisis, as well as the crisis period and after that, the impact of improving indicators of investment climate on the changing direction of FDI towards developing countries can be better evaluated. The historical trend in FDI inflows is also included in the analysis.

There are a couple of empirical studies focusing on the link between FDI and indicators of investment climate. Piwonski (2010), focusing on only one indicator of investment climate, shows that by increasing their country's "Ease of Doing Business" rank one level, a government can bring in over \$44 million USD as FDI. Morris and Aziz (2011) study the relationship between factors that affect conducting business and the inflows of FDI to Sub-Saharan Africa and Asian countries (57 countries in total). They focus on correlation coefficients between different variables between 2000 and 2005, but they do not include any regression analysis. When compared to our paper, Morris and Aziz (2011) focus on a limited time period and a limited number of analysis and countries. Still they have interesting outcomes. They find that two indicators, "registering property" and "trading across borders," were related to FDI inflows in these two regions of the world. Their paper provides empirical support to the hypothesis that FDI is related to investment climate. Nnadozie and Njuguna

\footnotetext{
${ }^{5}$ Many studies show that favorable business environments increase the chance of receiving more FDI inflows. See, for example, Dollar et al (2006), Kinda (2009), Mottaleb and Kalirajan (2010), Sekkat et al. (2007), and Tran (2008). Sekkat et al. (2007) define investment climate as infrastructure availability, sound economic and political conditions. Kinda (2009), Dollar et al. (2006) and Tran (2008) consider financial development and good institutions as determinants of successful business environments. Mottaleb and Kalirajan (2010) consider the rules and regulations relating to investment and business, as well as macroeconomic stability. These variables are also used in several papers including Botero et al. (2004), Djankov et al. (2002, 2003, and 2007).
} 
(2011) investigate the link between investment climate, in particular the prevailing business regulations, and FDI in the Africa region only. After running regressions which use business regulations as one of the independent variables, they find that business rules and regulations are important for FDI.

The outcomes of the empirical analysis in this paper show that countries with better investment climate indicators tend to attract more FDI inflows. Improvements in some "doing business" indicators have a statistically significant explanatory power in determining FDI inflows to developing countries. The highest correlation between indicators and FDI inflows belongs to starting a business, getting credit, protecting investors, and enforcing contracts. The regression results support the first set of findings: starting a business, investor protection, and cost of exports and imports are among the most significant determinants of FDI inflows. The estimated coefficients of regression analysis state that many doing business indicators are statistically significant determinants of FDI, even after controlling for other variables which can impact FDI inflows. For example, when we increase the strength of the investor protection index by 1 unit, the country can attract an increase of 0.65 percentage points in FDI inflows (in percent of GDP).

In Section 2, world trends in FDI are presented. In this section some country specific examples are also provided. Section 3 investigates the link between basic macroeconomic variables and FDI inflows. Section 4 focuses on the relationship between investment climate indicators and FDI inflows. Section 5 presents regression analysis where FDI inflows as a percent of GDP are the dependent variable. Section 6 concludes the paper.

\section{Recent Trends in FDI}

Between 2003 and 2008, the period prior to the global crisis, the total volume of FDI inflows was increasing tremendously. However, when the global crisis hit in 2008 and 2009, the trend reversed and FDI inflows declined significantly. United Nations Conference on Trade and Development (2009) indicates that in 2008 FDI inflows declined by almost15 percent from its historically high level of $\$ 1.9$ trillion in 2007. The same reports identify two reasons on why FDI inflows declined after the crisis: 1) the capacity of firms to invest was reduced by the declining availability of credits; 2) the tendency to invest declined negatively by changing economic conditions, especially in developed countries. Despite this downward trend in FDI inflows, especially towards developed countries, one interesting point is that even in the middle of the crisis in 2008, flows into developing countries had an increasing trend.

More recent data on FDI supports the changing direction of inflows towards developing countries. According to the United Nations Conference on Trade and Development (UNCTAD), inflows of FDI in the world were equal to \$1.12 trillion in 2010, slightly higher than the level in 2009 ( $\$ 1.11$ trillion). For the first time in history, the share of developing countries in the world FDI inflows passed the share of developed countries in 2010. Data analysis reported that more than $\$ 0.1$ trillion of FDI inflows flew towards China. Such high inflows make China the world's largest recipient of FDI. All developing countries were not that lucky in terms of attracting more FDI. For example, FDI flows into India dropped by nearly a third (to \$23.7 billion). The United States managed to preserve its location on the top of the list 
and was the world's largest receiver of FDI for a long period of time. But in 2013 China became the leader of the group. According to Economist (2011), flows of FDI to developed countries as a group declined by 7 percent after the global crisis, whereas those to the rest of the world increased by 10 percent.

The International Monetary Fund's World Economic Outlook Database has been used to extract the FDI series in this paper. In the database, FDI inflows are defined as follows:

FDI net inflows: Foreign direct investment (FDI) or foreign investment refers to the net inflows of investment to acquire a lasting management interest (10 percent or more of voting stock) in an enterprise operating in an economy other than that of the investor. It is the sum of equity capital, reinvestment of earnings, other long-term capital, and short-term capital as shown in the balance of payments. The net inflows are new investment inflows less disinvestment.

The FDI series from International Monetary Fund's World Economic Outlook Database support the observations given above. The trends in FDI inflows in the world are presented in Figure 1. The figure shows FDI inflows both in billions of current US dollars and in percent of world GDP (right scale). The figure indicates that FDI inflows increased continuously in the 1990s, but then dropped sharply after the year 2000 with the bursting of the technology bubble. Then it started rising again in 2003. In 2007 it reached a value more than US\$2,000 billion. This figure was almost 4 times larger than the level in 2003, which was around \$US 500 billion at that time. After the initial drop in FDI, it increased steadily up to US\$ 1.75 trillion in 2011. FDI dropped again in 2012 and then stayed almost constant in 2013.

Figure 2 presents the time trend for FDI inflows towards developing countries only. Developing countries include low-income countries, low middle-income countries, and high middle-income countries as defined by the World Bank. One observation is that the fluctuations in the level of FDI inflows towards developing countries are smoother relative to the world trend as presented in Figure 1. FDI inflows towards developing countries increased dramatically up to 2008. Especially in the 2000s, the upward trend became steeper. In percent of their GDP, the share of FDI inflows increased from only 0.1 percent in 1990 up to 3.8 percent in 2008. With the global crisis of 2008 and 2009, the FDI inflows declined in developing countries as well, but the drop was modest relative to the one observed in developed countries. After this initial decrease, the FDI inflows increased quickly and, in 2010 reached to a point even higher than the one observed before the crisis. Similar to the world trend, we observe a slight decline in FDI inflows in 2010 and 2012. 


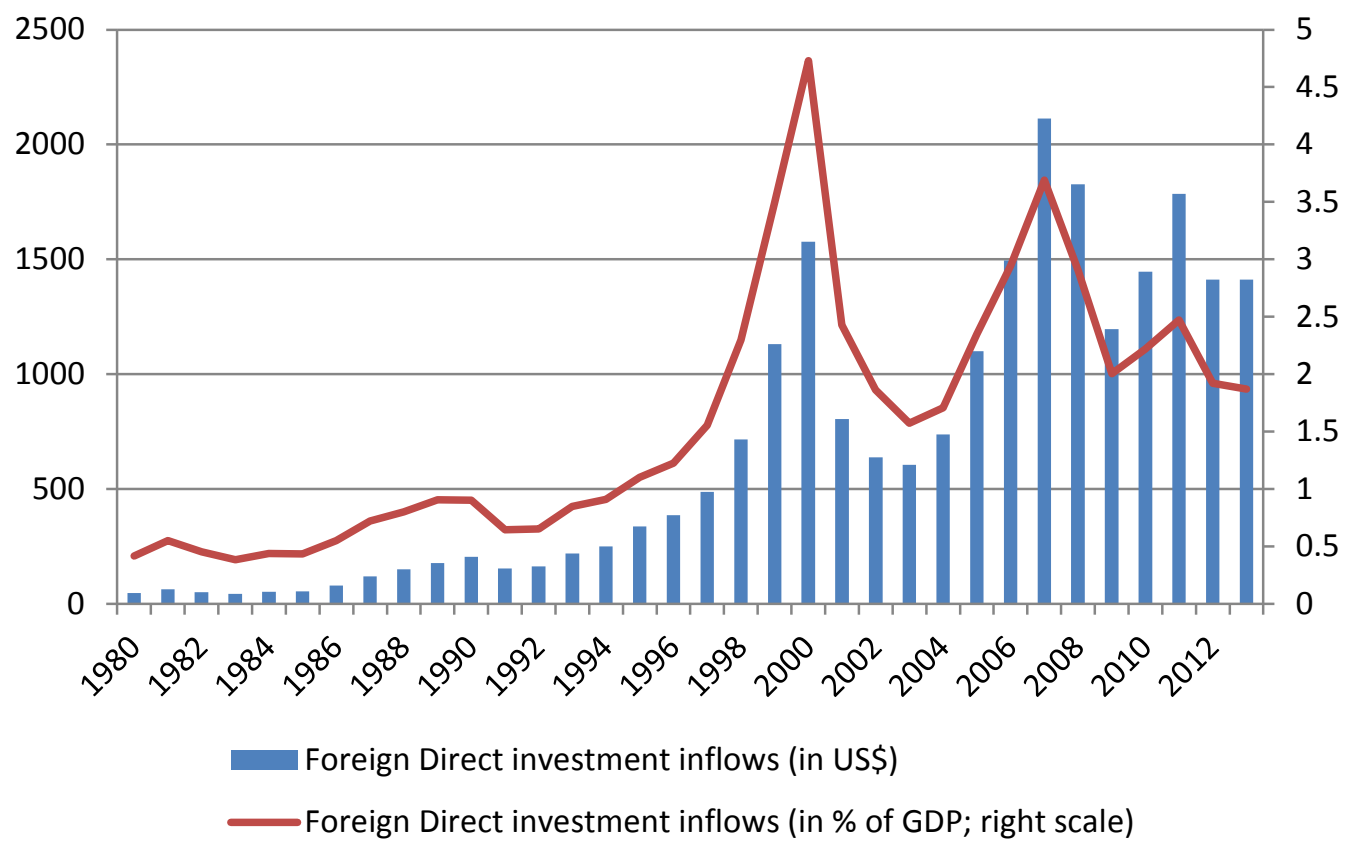

Figure 1. Foreign Direct Investment Inflows in the World, 1980-2013

Source: The author's calculation based on IMF's World Economic Outlook Database.

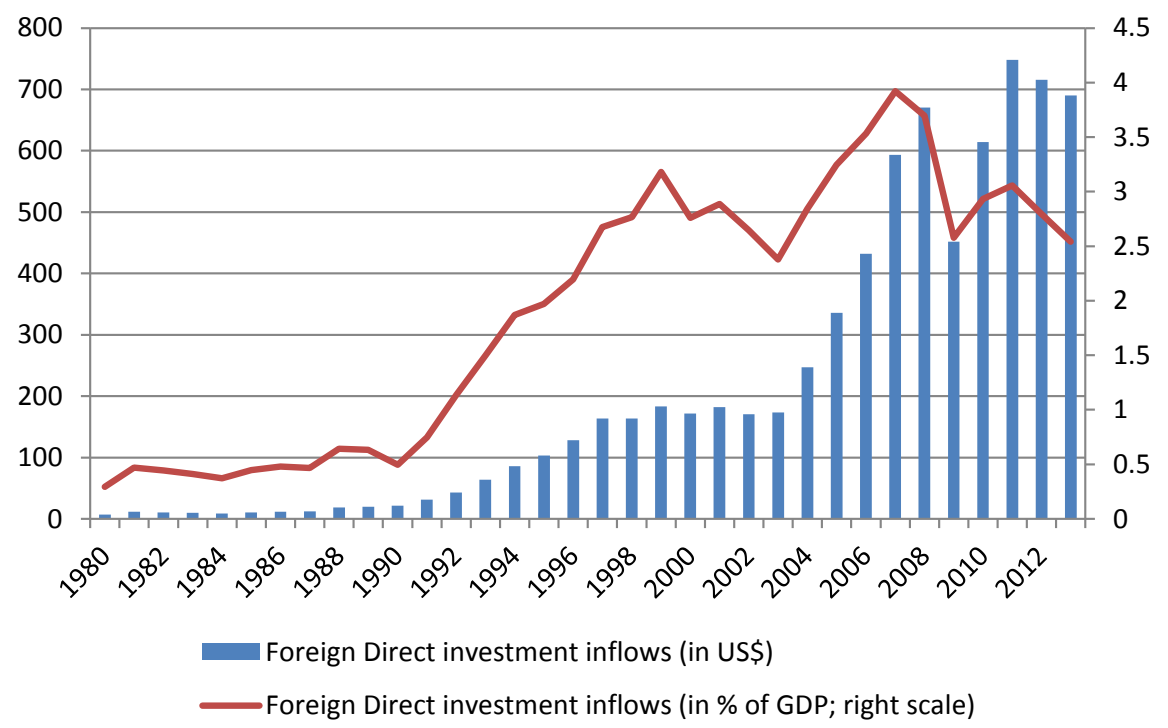

Figure 2. Developing Countries: Foreign Direct Investment Inflows, 1980-2013

Source: The author's calculation based on IMF's World Economic Outlook Database. 


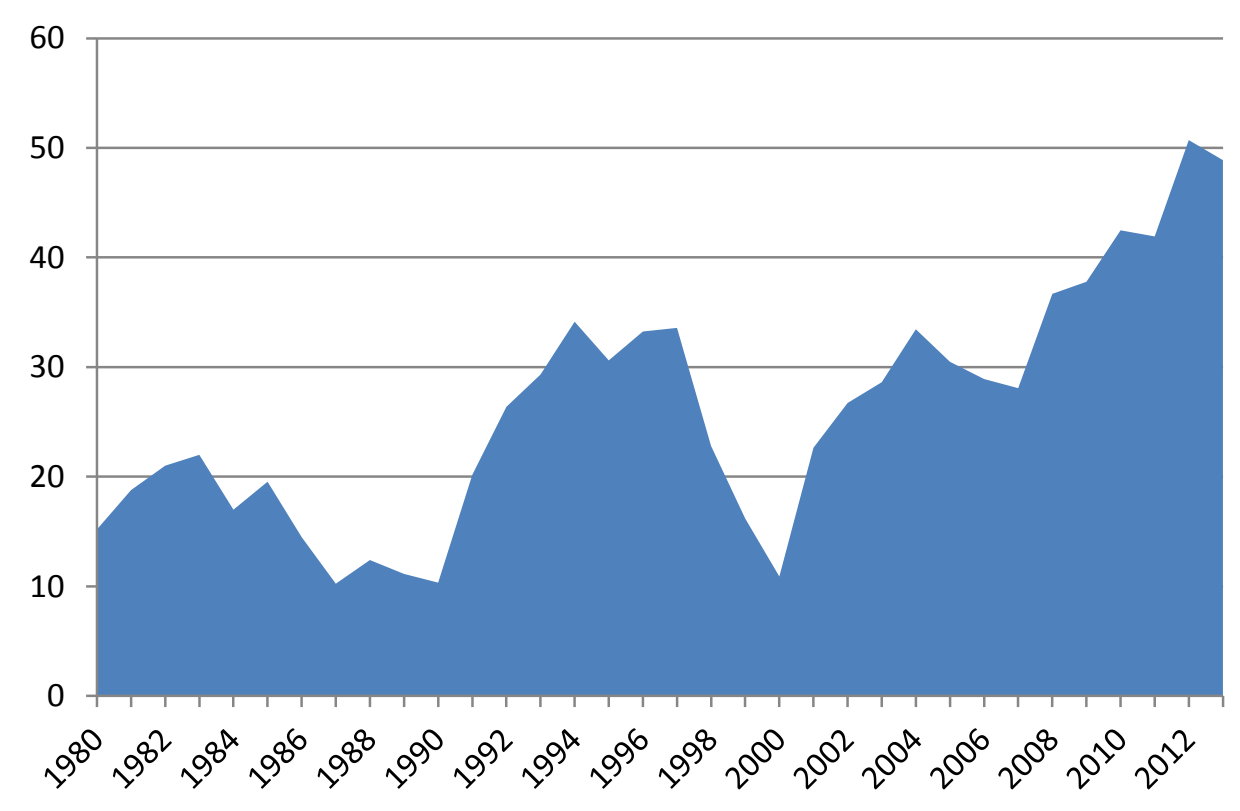

Figure 3. Share of Developing Countries' Foreign Direct Investment Inflows in Total Inflows in the World, 1980-2013

Source: The author's calculation based on IMF's World Economic Outlook Database.

The share of developing countries in the world is shown in Figure 3. The initial increasing trend in the share was reversed sharply during the Asian crisis in 1997 and 1998, but started to increase continuously shortly thereafter. In 2012 developing countries were able to attract more than 50 percent of total FDI flows in the world. Given the obvious significance of FDI in an economy, such a high point was a historical success for this group of countries.

Table 1 presents the top 15 FDI recipients in 2007 and in 2013. It should be noted that 2007 is the year right before the global crisis and 2013 is the latest year in our study. The top 15 FDI recipients collected almost 70 percent of FDI inflows in the world. When we compared the ranking in 2007 versus in 2013, it can be easily seen that the top countries and their rankings have changed significantly after the crisis. The United States was the highest FDI recipient country in 2007, but its ranking dropped to number 2 in 2013. China, which was ranked third in 2007, became the largest recipient in 2013. While China received 16.7 percent of global FDI inflows in 2013, the US attracted almost 14 percent of total inflows. The share of China was only 7.4 percent in 2007, right before the crisis. Another interesting point is that all BRIC countries were placed in the top 15 group in 2013, while only China and Russia was in the group in 2007. Table 1 also presents that the share of European countries in total FDI inflows declined during the crisis period. The FDI share of developing countries in the top group jumped from 15 percent in 2007 to almost 40 percent in 2013. These numbers indicate that the share of developing countries in the top group increased nearly 3 times between 2007 and 2013. 
Table 1. Top15 FDI Recipients (2007 versus 2013)

\begin{tabular}{|c|c|c|c|c|c|c|}
\hline \multirow[b]{2}{*}{ Rank } & \multicolumn{3}{|c|}{2007} & \multicolumn{3}{|c|}{2013} \\
\hline & & $\begin{array}{c}\text { FDI inflows } \\
\text { (in US\$) }\end{array}$ & $\begin{array}{l}\text { FDI inflows } \\
(\% \text { of GDP })\end{array}$ & & $\begin{array}{c}\text { FDI } \\
\text { inflows } \\
\text { (in }\end{array} \mid$ & $\begin{array}{l}\text { FDI inflows } \\
(\% \text { of GDP })\end{array}$ \\
\hline 1 & United States & 221.17 & 10.47 & China & 236.27 & 16.73 \\
\hline 2 & United Kingdom & 200.12 & 9.47 & United States & 193.36 & 13.69 \\
\hline 3 & China & 156.25 & 7.39 & Hong Kong (China) & 71.42 & 5.06 \\
\hline 4 & Netherlands & 119.55 & 5.66 & Brazil & 64.05 & 4.54 \\
\hline 5 & Canada & 116.82 & 5.53 & Singapore & 63.93 & 4.53 \\
\hline 6 & France & 96.36 & 4.56 & Canada & 62.32 & 4.41 \\
\hline 7 & Belgium & 93.56 & 4.43 & Russia & 61.80 & 4.38 \\
\hline 8 & Germany & 80.32 & 3.80 & United Kingdom & 55.91 & 3.96 \\
\hline 9 & Spain & 64.36 & 3.05 & Australia & 49.09 & 3.48 \\
\hline 10 & Austria & 62.51 & 2.96 & Spain & 39.16 & 2.77 \\
\hline 11 & Russia & 55.07 & 2.61 & Ireland & 35.53 & 2.52 \\
\hline 12 & Hong Kong (China) & 54.34 & 2.57 & Mexico & 35.19 & 2.49 \\
\hline 13 & Singapore & 47.73 & 2.26 & Germany & 26.73 & 1.89 \\
\hline 14 & Australia & 44.76 & 2.12 & India & 25.25 & 1.79 \\
\hline 15 & Italy & 43.91 & 2.08 & Netherlands & 21.48 & 1.52 \\
\hline
\end{tabular}

Source: The author's calculation based on IMF's World Economic Outlook Database.

The BRIC countries attract special attention due to the fact that they are all large developing countries whose growth performance can have significant impact in the world. Figure 4 presents the time trend of FDI inflows for the BRIC countries. Despite the fact that there are some fluctuations, it is obvious that FDI inflows have an increasing trend in these countries, especially in China. While Brazil and Russia attract almost the same level of FDI inflows, India collects the lowest FDI in the group.

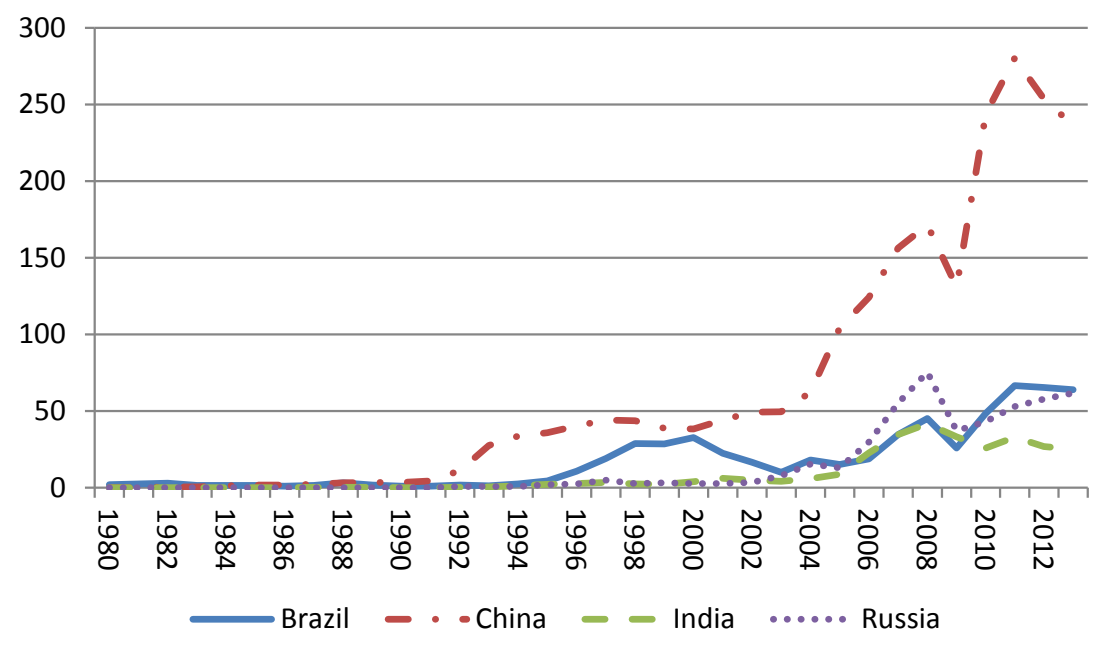

Figure 4. Foreign Direct Investment Inflows in BRIC countries (in US\$), 1980-2013

Source: The author's calculation based on IMF's World Economic Outlook Database. 


\section{Link between FDI Inflows and Basic Macroeconomic Indicators}

In the absence of stable growth rates in advanced economies in recent years, developing countries have been considered the new engines of growth. The analysis in Section 2 shows that this group of countries has attracted more and more FDI flows in recent years. In addition to improving investment climate of developing countries, their superior economic performance can be one possible reason for higher FDI inflows. The purpose of this paper is to link FDI inflows to investment climate, but we need to check for other possible explanations as well in order to better evaluate the impact of investment climate. In light of this argument, this section tries to answer the question of what the role of improving macroeconomic indicators in developing countries would be in this changing trend of FDI inflows.

Since the focus of this paper is on developing countries, we consider only the top 30 developing countries in terms of FDI inflows. ${ }^{6}$ The reason is that a large number of developing countries unfortunately cannot attract enough FDI inflows and thus their impact in a FDI analysis is negligible. Therefore, we focus on top recipients only. The ranking is based on average FDI, received between 2008 and 2013. The top 30 developing countries receive almost 90 percent of total FDI flows towards developing countries. This means that FDI inflows have been collected almost entirely by the top developing countries. The basic macroeconomic indicators studied in this section are the growth rate of real GDP, GDP per capita in constant 2005 US\$, real GDP in constant 2005 US\$, gross fixed investment, trade openness, and the corruption index. The data source for these macroeconomic variables is the World Bank's World Development Indicators.

A scatter diagram between the growth rate of real GDP and the growth rate of FDI inflows is presented in the first panel of Figure 5. It covers averages between 2004 and 2013, corresponding to the period during which developing countries started attracting higher shares of FDI inflows. Each point in the figure corresponds to a country average for the period between 2004 and 2013. In Panel A the simple correlation between the two variables is 0.56 (significant at 1 percent). This relatively high correlation is confirmed with an upward trend in the figure. It means that faster growing developing countries can collect an increasing rate of FDI inflows.

Panel B of the same figure shows the link between the log of GDP and the log of FDI inflows, both of which are in U.S. dollars. It can be seen that the relationship between the two variables is relatively strong with a simple correlation coefficient equal to 0.60 (significant at 1 percent); indicating that larger economies receive a larger amount of FDI inflows.

In Panel C a scatter diagram is presented between GDP per capita (in constant 2000 US\$) and FDI inflows in percent of GDP. The simple correlation coefficient is relatively weak. It is positive, but its value is only 0.29 (significant at 1 percent). This low value indicates that higher income levels do not help much in attracting more FDI. This finding supports the findings in the previous section. The income level of countries is not a strong determinant of FDI inflows.

\footnotetext{
${ }^{6}$ The countries are Argentina, Brazil, Chile, China, Colombia, Hong Kong (China), India, Indonesia, Iraq, Kazakhstan, Korea, Lebanon, Malaysia, Mexico, Morocco, Mozambique, New Zealand, Nigeria, Panama, Peru, Philippines, Russia, Saudi Arabia, Singapore, South Africa, Taiwan (China), Thailand, Turkey, United Arab Emirates, and Vietnam.
} 


\section{Macrothink}

Some lower income countries can attract more FDI under the right conditions in a given moment.

Panel D shows the link between trade openness and FDI. It is expected that countries with higher trade openness to have freer capital markets; as a result, they can collect more FDI. Indeed, the link between trade openness (imports plus exports in percent of GDP) and FDI in percent of GDP are relatively high. The simple correlation between these two variables is 0.53 (significant at 1 percent). So we can consider trade openness as one determinant of FDI.

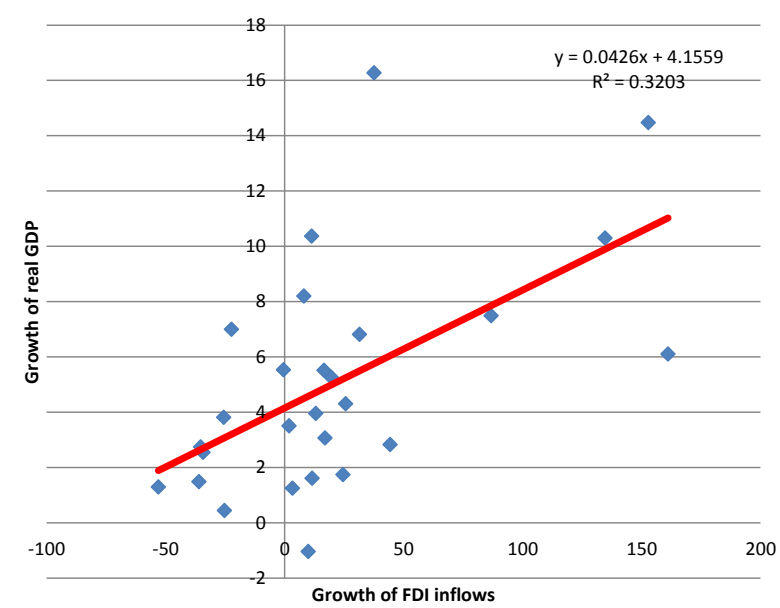

Panel A: Economic growth and FDI

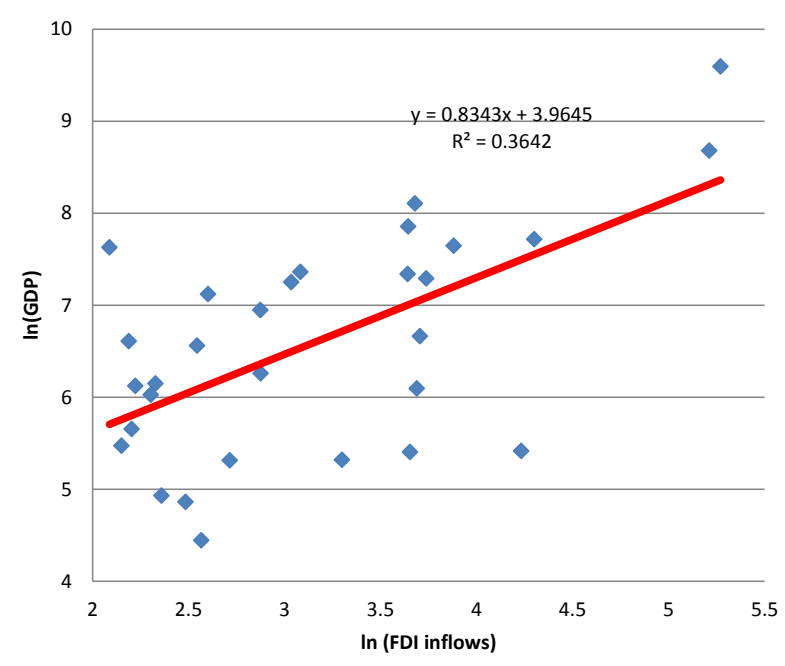

Panel B: Size of economy and FDI

Figure 5. Top 30 FDI Recipient Developing Countries: Foreign Direct Investment Inflows and Macroeconomic Indicators, 2004-2013 


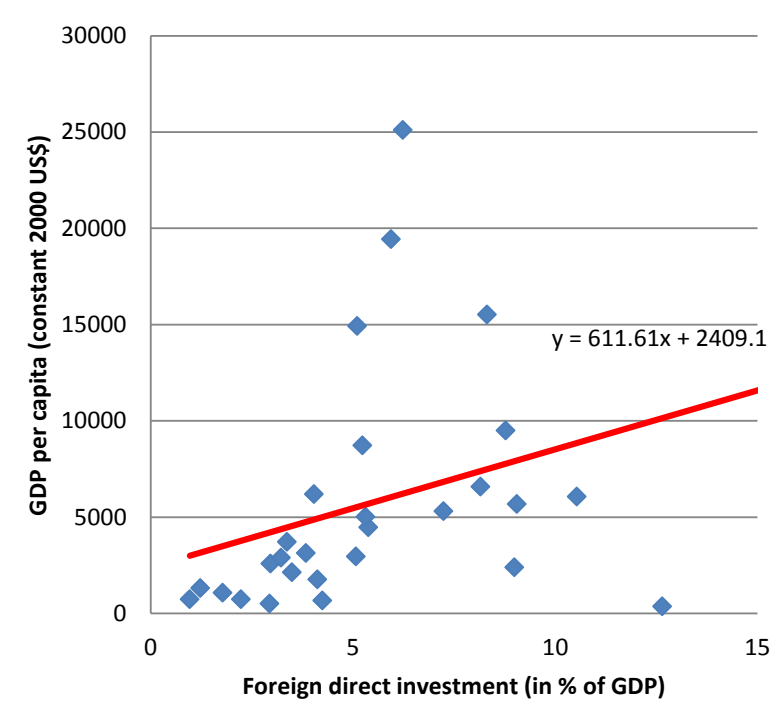

Panel C: Per capita income and FDI

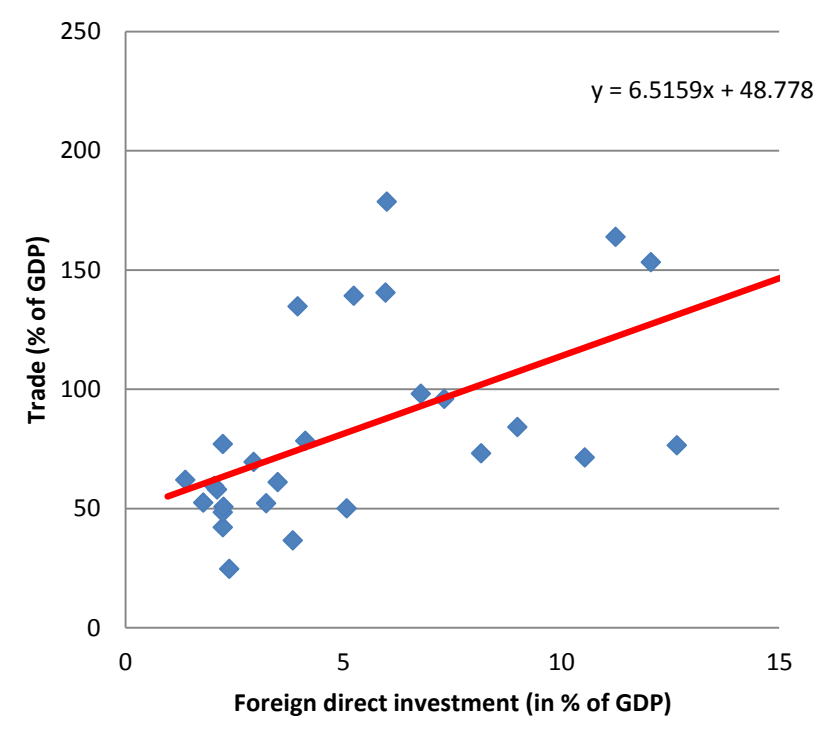

Panel D: Trade openness and FDI

Figure 5 (Continued). Top 30 FDI Recipient Developing Countries: Foreign Direct Investment Inflows and Macroeconomic Indicators, 2004-2013

The level of gross fixed investment can be an important determinant of FDI. Because countries with higher investment rates are expected to grow faster, foreign investors, especially the ones making direct investments, will be more willing to participate in the production process of those countries. Panel E of Figure 5 supports this expectation. It shows a strong positive link between gross fixed investment and FDI, with a simple correlation of 0.67 (significant at 1 percent).

The last macroeconomic variable investigated in this section is an indicator of governance quality. It is expected that foreign investors prefer countries with a higher quality of 


\section{Macrothink}

Business and Economic Research

ISSN 2162-4860 2015, Vol. 5, No. 1

governance. The corruption index is used as an indicator for this purpose. Despite our expectations, in Panel F we do not observe a strong link between corruption index (please note that higher values indicate lower corruption) and FDI. The simple correlation is only 0.18 (significant at 1 percent). The correlation is not strong, but since we still believe that it is important to control for the possible impacts of at least one institutional quality index on FDI, this variable is included in the regression specification as will be explained in Section 5.

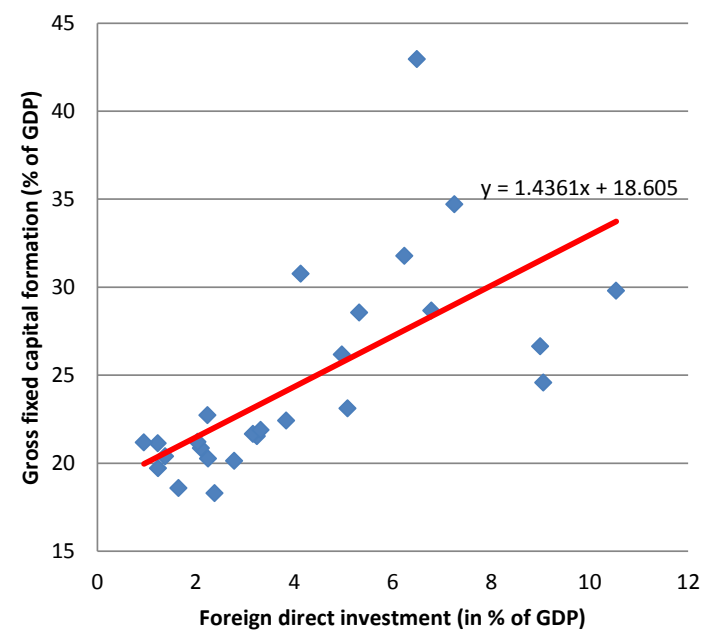

Panel E: Gross fixed investment and FDI

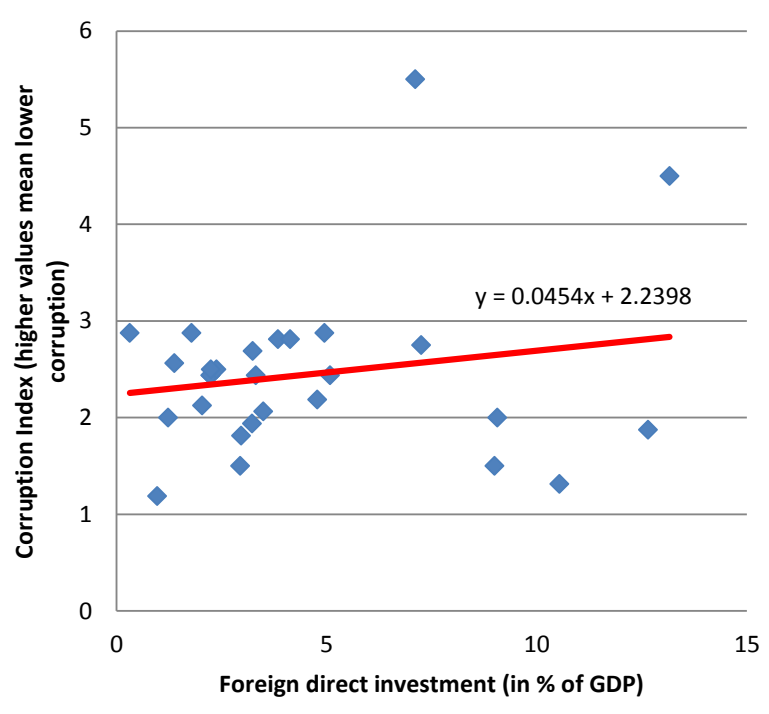

Panel F: Governance quality index and FDI

Figure 5 (Concluded). Top 30 FDI Recipient Developing Countries: Foreign Direct Investment Inflows and Macroeconomic Indicators, 2004-2013

Source: The author's calculation based on IMF's World Economic Outlook and the World Bank's World Development Indicators Databases. 


\section{Macrothink}

\section{Link between FDI Inflows and "Ease of Doing Business"}

The International Monetary Fund (1993) in the Balance of Payments Manual defines FDI as follows:

FDI refers to an investment made to acquire lasting interest in enterprises operating outside of the economy of the investor. Further, in cases of FDI, the investor's purpose is to gain an effective voice in the management of the enterprise.

This definition indicates that investment climate indicators as given in the Doing Business Database can be important candidates while explaining FDI inflows in a country. Countries with a climate in which firms feel more comfortable in terms of business friendliness should attract more foreign direct investment.

The main data source for investment climate indicators is the World Bank's Doing Business Database, covering the years from 2004 to 2013. The methodology of this database is that the World Bank collaborates with academic professionals to design a business case survey. This method includes a business scenario and asks questions about how that firm would react to this scenario. Annually, the survey is distributed to nearly 8,000 local experts per economy, such as lawyers, consultants, accountants, supply chain professionals, government officials, and other businesspeople routinely administering or consulting foreign firms. The methodology also includes direct contact with the professionals.

In the database, there are different variables that measure business friendliness of countries. They are mostly index numbers. The main groups of indicators in the Doing Business Database are:

- "Starting a business" indicators

- "Dealing with Construction Permits" indicators

- "Registering Property" indicators

- "Getting credit" indicators

- "Protecting investors" indicators

- "Paying Taxes" indicators

- "Trading Across Borders" indicators

- "Enforcing Contracts" indicators

- "Resolving Insolvency" indicators

Each group consists of several variables:

Starting a Business

- Procedures (number)

- Time (days)

- Cost (\% of income per capita)

- Paid-in Min. Capital (\% of income per capita)

\section{Dealing with Construction Permits}

- Procedures (number) 
- Time (days)

- Cost (\% of income per capita)

\section{Registering Property}

- Procedures (number)

- Time (days)

- Cost (\% of property value)

\section{Getting Credit}

- Strength of legal rights index (0-10)

- Depth of credit information index (0-6)

- Public registry coverage (\% of adults)

- Private bureau coverage ( $\%$ of adults)

\section{Protecting Investors}

- Extent of disclosure index (0-10)

- Extent of director liability index (0-10)

- Ease of shareholder suits index (0-10)

- Strength of investor protection index (0-10)

\section{Paying Taxes}

- Payments (number per year)

- Time (hours per year)

- Total tax rate (\% profit)

\section{Trading Across Borders}

- Documents to export (number)

- Time to export (days)

- Cost to export (US\$ per container)

- Documents to import (number)

- Time to import (days)

- Cost to import (US\$ per container)

\section{Enforcing Contracts}

- Time (days)

- Cost (\% of claim)

- Procedures (number)

\section{Resolving Insolvency}

- Time (years)

- Recovery rate (cents on the dollar) 


\section{Mll Macrothink}

Business and Economic Research

ISSN 2162-4860

2015, Vol. 5, No. 1

Some doing business indicators have been criticized because of their methodology and the presentation of the data collected. However, it should be pointed out that these indicators are the only available set of data points that provide an objective, world-wide comparison of indicators of investment climate. The Doing Business report has recently been reviewed by an independent panel constituted by the President of the World Bank. ${ }^{7}$ In general, the comments include that "reducing the amount of time and money spent on starting a business can be important. However, doing so is not in any way enough to guarantee economic success. Here, deregulation would generally be viewed as worthwhile. ... Finding ways to better protect private investors is not about deregulation but about improving regulation to encourage outside investment." (Independent Panel Report, 2013 page 15). The panel did raise questions about the methodology of some indicators, but they agree that the doing business indicators could be useful in empirical analysis in many ways. We believe that the indicators used in this study are good and useful measures of countries' investment climate.

The first step of understanding the importance of doing business indicators on FDI would be the calculation of simple correlation coefficients between FDI and the indicators. Table 2 presents the expected signs of the correlation coefficients and the actual correlation. It can be seen that in almost each case, the expected sign and the actual sign of the coefficients are identical. All indicators of starting a business (number of procedures, time requirement in days, cost of starting a business, and paid-in minimum capital) have a negative coefficient. For example, the correlation coefficient between the number of days to start a business and FDI inflows to this country is -0.63 on average (significant at 1 percent). It means that the lower number of days to start a business makes a difference in terms of attracting more FDI inflows. Similarly, the correlation coefficient between the cost of starting a business in percent of income per capita and FDI inflows to the country in percent of GDP is -0.63 on average (significant at 1 percent). The lower cost of starting a business increases FDI inflows.

Table 2 also shows that the easier it is to get construction permits in terms of the number of procedures, required time, and cost, the higher the FDI inflows are. The correlation coefficients for these variables are between -0.42 and -0.69 (all significant at 1 percent). As an example, as the cost of dealing with construction permits declines, FDI inflows increase (the simple correlation coefficient is -0.69 ).

In the developing countries we find that the indicators of registering property and FDI inflows are negatively linked. The lower the number of procedures, the shorter the time and the lower the cost of registering property, the higher the FDI inflows are. Some getting credit indicators are highly significant determinants of FDI inflows. Countries with better qualities of getting credit indicators can receive a larger amount of FDI inflows. For example, as the strength of legal rights increases, FDI inflows strongly increase as well (the simple correlation coefficient is 0.75 (significant at 1 percent)).

\footnotetext{
${ }^{7}$ Independent Panel Review of the Doing Business Report, June 2013, http://www.dbrpanel.org/sites/dbrpanel/files/doing-business-review-panel-report.pdf
} 
Table 2. Top 30 FDI Recipient Developing Countries: Correlation Coefficient between FDI in \% of GDP and Different "Doing Business" Indicators (averages between 2004 and 2013)

\begin{tabular}{|c|c|c|}
\hline Expected sign of correlation coef. & & Correlation coefficient \\
\hline & Starting a Business & \\
\hline- & Procedures (number) & $-0.54 *$ \\
\hline- & Time (days) & $-0.69 *$ \\
\hline- & Cost (\% of income per capita) & $-0.63 *$ \\
\hline \multirow[t]{2}{*}{-} & Paid-in Min. Capital (\% of income per capita) & $-0.58 *$ \\
\hline & Dealing with Construction Permits & \\
\hline- & Procedures (number) & $-0.51 *$ \\
\hline- & Time (days) & $-0.42 *$ \\
\hline \multirow[t]{2}{*}{-} & Cost (\% of income per capita) & $-0.69 *$ \\
\hline & Registering Property & \\
\hline- & Procedures (number) & $-0.48 *$ \\
\hline- & Time (days) & $-0.58 *$ \\
\hline \multirow[t]{2}{*}{-} & Cost (\% of property value) & $-0.23 *$ \\
\hline & Getting Credit & \\
\hline+ & Strength of legal rights index $(0-10)$ & $0.75^{*}$ \\
\hline+ & Depth of credit information index $(0-6)$ & $0.60 *$ \\
\hline+ & Public registry coverage ( $\%$ of adults) & $0.40^{*}$ \\
\hline \multirow[t]{2}{*}{+} & Private bureau coverage ( $\%$ of adults) & $0.34 *$ \\
\hline & Protecting Investors & \\
\hline+ & Extent of disclosure index $(0-10)$ & $0.52 *$ \\
\hline+ & Extent of director liability index (0-10) & $0.46^{*}$ \\
\hline+ & Ease of shareholder suits index (0-10) & $0.43^{*}$ \\
\hline \multirow[t]{2}{*}{+} & Strength of investor protection index (0-10) & $0.41 *$ \\
\hline & Paying Taxes & \\
\hline- & Payments (number per year) & $-0.41 *$ \\
\hline- & Time (hours per year) & -0.06 \\
\hline \multirow[t]{2}{*}{-} & Total tax rate (\% profit) & $-0.24 *$ \\
\hline & Trading Across Borders & \\
\hline- & Documents to export (number) & $-0.26 *$ \\
\hline- & Time to export (days) & $-0.44 *$ \\
\hline- & Cost to export (US\$ per container) & $0.46^{*}$ \\
\hline- & Documents to import (number) & $-0.51 *$ \\
\hline- & Time to import (days) & $-0.50 *$ \\
\hline \multirow[t]{2}{*}{-} & Cost to import (US\$ per container) & $0.41^{*}$ \\
\hline & Enforcing Contracts & \\
\hline- & Procedures (number) & $-0.55^{*}$ \\
\hline- & Time (days) & $-0.32 *$ \\
\hline \multirow[t]{2}{*}{ - } & Cost (\% of claim) & 0.01 \\
\hline & Resolving Insolvency & \\
\hline+ & Recovery rate (cents on the dollar) & $0.28 *$ \\
\hline- & Time (years) & $-0.18 *$ \\
\hline
\end{tabular}

Source: The author's calculation based on IMF's World Economic Outlook and the World Bank's Doing Business Indicators Databases.

Note: * stands for 1 percent significance level. 


\section{MlMacrothink}

Business and Economic Research

ISSN 2162-4860

2015, Vol. 5, No. 1

The indicators for protecting investors are expected to have positive effects on FDI inflows. While the correlation coefficient for the extent of disclosure index is 0.52 , it is 0.41 for the strength of investor protection index (all significant at 1 percent). Taxes, on the other hand, have negative impacts on FDI. Foreign investors prefer countries with lower tax burdens. The findings in section 3 indicated that trade openness is very important for FDI inflows. These outcomes are supported in Table 2. As the number of documents and time to export and import declines, inflows of FDI increase. The only exceptions are the cost to export and import. The simple correlation coefficients for these variables state that the sign is positive despite the fact that the expected sign was negative. It means that higher costs of trade do not stop FDI inflows. Most indicators of enforcing contracts have the expected sign. While the two sub-indicators of enforcing contracts (the number of procedures and required days) have a negative and relatively strong effect on FDI inflows, the cost of enforcing contracts is not significant.

Figure 6 presents the link between "ease of doing business" ranking of the top 30 FDI recipient developing countries and FDI inflows in percent of GDP. It should be noted that the higher the value of the ease of doing business rank, the worse the position of the country is. The figure shows the ranking of countries, which is calculated by taking into account all available "doing business" indicators listed in the previous section. The relationship is negative as expected. A higher ranking in business friendliness, corresponding to the lower numbers on the y-axis, is expected to attract more FDI inflows. The relationship is indeed negative with a simple correlation coefficient of -0.49 between the two variables (significant at 1 percent).

Table 3 presents enormous improvements in the investment climate of the top 30 FDI recipient developing countries between 2004 and 2013. For each indicator, annual averages are calculated for the group of countries. The results clearly indicate that developing countries deserve receiving higher shares of FDI inflows as they improve their business friendliness considerably. As presented in the last column of the table, the changes in the values of each doing business indicator move in the right direction: while costs or burdens are declining, benefits or rewards are increasing. In the "starting a business" set, the number of procedures declined by 26 percent; time by 60 percent; cost by 56 percent; and paid-in minimum capital by 93 percent. Similarly, all the indicators under "dealing with construction permits" dropped significantly. The number of procedures is 17 percent lower; the required time is 25 percent lower; and the cost is 67 percent lower. The "registering property" indicators are also in much better shape. The number of procedures, the time required and the cost have all have lower values in 2013 compared to their values in 2004. 


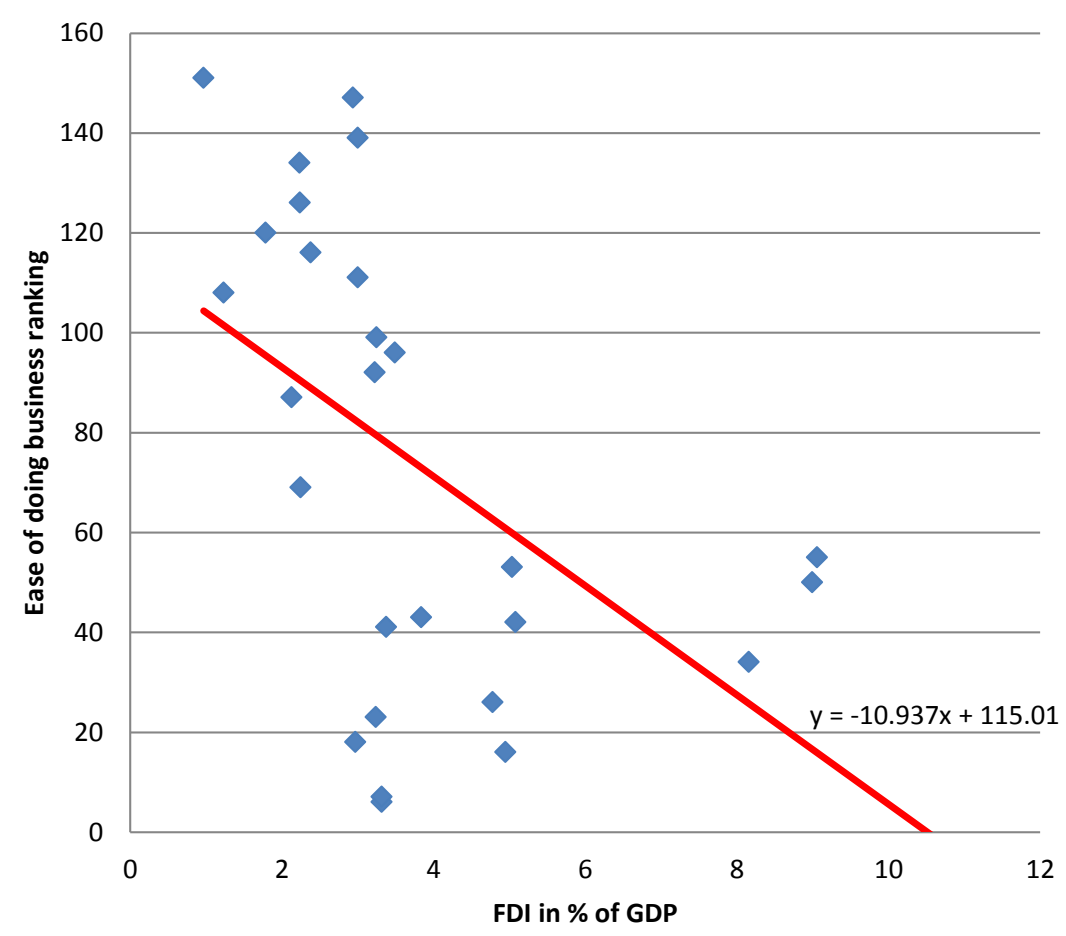

Figure 6. Top 30 Developing Countries: Foreign Direct Investment Inflows and "Ease of Doing” Ranking, 2004-2013

Source: The authors' calculation based on "Doing Business" database.

The indicators of "getting credit" and "protecting investors" are expected to be significant determinants of FDI inflows. The values of these indicators increased substantially between 2004 and 2013. The strength of legal rights and the depth of credit information increased in 2013. Similarly, public registry coverage and private bureau coverage expanded between 2004 and 2013. Investors were better protected in 2013, compared to 2004. All indicators of "protecting investors" exhibited higher values in 2013.

Tax systems became simpler on average. The number of payments and the time spent for tax compliance dropped significantly, as well as the total tax rate. Such improvements in the tax system can help attract more foreign investors. The indicators of easiness of trade (exports and imports) also improved. In 2013 international trade required less documents and less time. Only the costs to export and import were higher. Given that the costs are in current U.S. dollar terms, the higher figures may reflect higher costs of transportation, especially the impact of higher oil prices.

It became easier to "enforce contracts" in 2013. It takes a less amount of time; the cost is lower; and the number of procedures to follow is less. "Closing a business" can affect foreign investors considerably. They may invest more confidently if they resolve insolvency more easily. Indeed, the recovery rate is almost 15 percent higher in 2013, while the required time to resolve any insolvency is 17 percent lower.

The results in Table 3 have important implications in terms of how developing countries have 


\section{Macrothink}

Business and Economic Research

ISSN 2162-4860

2015, Vol. 5, No. 1

been attracting more foreign funds. In addition to improving their macroeconomic conditions, developing countries also became more business friendly. Under such favorable conditions, they were able to increase the long-term involvement of foreign investors in their economies.

Table 3. Top 30 FDI Recipient Developing Countries: Improvements in Business Friendliness (averages over 2004-2013)

\begin{tabular}{|c|c|c|c|c|c|c|c|c|c|c|c|}
\hline Starting a Business & 2004 & 2005 & 2006 & 2007 & 2008 & 2009 & 2010 & 2011 & 2012 & 2013 & $\%$ change \\
\hline Procedures (number) & 9.8 & 9.6 & 9.6 & 9.2 & 9.1 & 8.6 & 8.2 & 7.5 & 7.4 & 7.2 & -26.4 \\
\hline Time (days) & 49.9 & 47.1 & 39.4 & 35.0 & 30.7 & 26.0 & 23.5 & 21.7 & 20.7 & 19.7 & -60.4 \\
\hline Cost (\% of income per capita) & 32.1 & 29.7 & 27.8 & 24.7 & 25.4 & 18.8 & 19.9 & 17.9 & 16.0 & 14.2 & -55.6 \\
\hline Paid-in Min. Cap. (\%of income p.c.) & 154.9 & 139.5 & 83.5 & 49.2 & 46.3 & 18.1 & 16.4 & 13.6 & 11.6 & 10.5 & -93.3 \\
\hline \multicolumn{12}{|l|}{ Dealing with Construction Permits } \\
\hline Procedures (number) & & 19.5 & 19.6 & 19.4 & 19.1 & 18.5 & 17.8 & 17.8 & 17.2 & 16.1 & -17.4 \\
\hline Time (days) & & 191.3 & 184.7 & 7185.8 & 8181.2 & 174.4 & 165.5 & 162.1 & 150.0 & 142.9 & -25.3 \\
\hline Cost (\% of income per capita) & & 923.9 & 716.9 & 685.6 & 6528.8 & 445.7 & 431.4 & 374.2 & 331.2 & 310.3 & -66.4 \\
\hline \multicolumn{12}{|l|}{ Registering Property } \\
\hline Procedures (number) & 6.1 & 6.1 & 6.1 & 6.2 & 6.1 & 6.0 & 6.0 & 6.0 & 6.0 & 5.9 & -3.3 \\
\hline Time (days) & 39.4 & 39.8 & 39.1 & 38.9 & 37.4 & 35.1 & 31.7 & 31.6 & 30.5 & 27.9 & -29.2 \\
\hline Cost (\% of property value) & 5.9 & 5.1 & 4.9 & 4.9 & 4.7 & 4.6 & 4.7 & 4.6 & 4.6 & 4.7 & -20.2 \\
\hline \multicolumn{12}{|l|}{ Getting Credit } \\
\hline Strength of legal rights index $(0-10)$ & 5.2 & 5.2 & 5.3 & 5.5 & 5.5 & 5.5 & 5.6 & 5.7 & 5.7 & 5.7 & 11.0 \\
\hline Depth of credit information index (0-6) & 3.4 & 3.6 & 4.0 & 4.2 & 4.5 & 4.7 & 4.8 & 4.8 & 4.9 & 5.0 & 48.5 \\
\hline Public registry coverage ( $\%$ of adults) & 3.9 & 4.0 & 5.7 & 6.4 & 11.2 & 11.7 & 12.7 & 14.1 & 15.4 & 16.1 & 317.5 \\
\hline Private bureau coverage ( $\%$ of adults) & 20.8 & 26.1 & 26.8 & 28.7 & 31.8 & 36.5 & 37.9 & 42.5 & 43.9 & 46.2 & 122.1 \\
\hline \multicolumn{12}{|l|}{ Protecting Investors } \\
\hline Extent of disclosure index $(0-10)$ & & 6.8 & 6.9 & 7.0 & 7.1 & 7.1 & 7.2 & 7.2 & 7.3 & 7.5 & 9.8 \\
\hline Extent of director liability index (0-10) & & 4.3 & 4.4 & 4.5 & 4.7 & 4.9 & 4.9 & 5.1 & 5.2 & 5.3 & 24.2 \\
\hline Ease of shareholder suits index (0-10) & & 5.6 & 5.6 & 5.7 & 5.7 & 5.7 & 5.8 & 6.0 & 6.0 & 6.0 & 7.8 \\
\hline Strength of investor protection $(0-10)$ & & 5.5 & 5.7 & 5.7 & 5.8 & 5.9 & 6.0 & 6.1 & 6.2 & 6.3 & 12.8 \\
\hline \multicolumn{12}{|l|}{ Paying Taxes } \\
\hline Payments (number per year) & & 26.0 & 24.6 & 24.6 & 20.9 & 19.5 & 19.4 & 17.8 & 17.6 & 16.5 & -36.5 \\
\hline Time (hours per year) & & 442.7 & 443.9 & 420.6 & 6397.1 & 386.7 & 375.0 & 359.1 & 346.4 & 344.3 & -22.2 \\
\hline Total tax rate (\% profit) & & 44.3 & 44.2 & 43.6 & 43.5 & 41.8 & 40.9 & 40.8 & 40.7 & 40.7 & -8.3 \\
\hline \multicolumn{12}{|l|}{ Trading Across Borders } \\
\hline Documents to export (number) & & 6.1 & 6.0 & 5.8 & 5.7 & 5.7 & 5.6 & 5.6 & 5.5 & 5.5 & -9.8 \\
\hline Time to export (days) & & 24.4 & 23.6 & 22.3 & 21.3 & 20.8 & 19.3 & 19.0 & 18.6 & 18.3 & -24.9 \\
\hline Cost to export (US\$ per container) & & 939 & 950 & 951 & 1068 & 1096 & 1111 & 1151 & 1236 & 1256 & 33.7 \\
\hline Documents to import (number) & & 8.1 & 7.8 & 7.3 & 7.1 & 6.9 & 6.8 & 6.8 & 6.9 & 6.8 & -15.7 \\
\hline Time to import (days) & & 28.0 & 26.9 & 24.3 & 23.2 & 22.4 & 20.8 & 20.5 & 20.5 & 20.1 & -28.3 \\
\hline Cost to import (US\$ per container) & & 1105 & 1095 & 1042 & 1186 & 1213 & 1229 & 1278 & 1373 & 1398 & 26.5 \\
\hline \multicolumn{12}{|l|}{ Enforcing Contracts } \\
\hline Time (days) & 573.5 & 569.4 & 557.6 & 5557.6 & 6556.6 & 557.1 & 557.1 & 553.8 & 551.7 & 548.8 & -4.3 \\
\hline Cost (\% of claim) & 35.7 & 35.7 & 35.7 & 35.7 & 35.2 & 35.0 & 35.0 & 35.0 & 35.1 & 35.2 & -1.4 \\
\hline Procedures (number) & 37.4 & 37.3 & 37.2 & 37.2 & 37.1 & 37.1 & 37.0 & 36.9 & 36.8 & 36.8 & -1.8 \\
\hline \multicolumn{12}{|l|}{ Resolving Insolvency } \\
\hline Time (years) & 3.1 & 3.1 & 2.8 & 2.8 & 2.8 & 2.8 & 2.8 & 2.7 & 2.7 & 2.6 & -17.4 \\
\hline Recovery rate (cents on the dollar) & 35.2 & 36.8 & 37.5 & 37.8 & 37.5 & 37.5 & 39.0 & 40.0 & 39.7 & 40.8 & 15.9 \\
\hline
\end{tabular}

Source: The authors' calculation based on "Doing Business" database. 


\section{Regression Analysis: Determinants of Foreign Direct Investment in Developing Countries}

The previous sections show that there are several candidates, including doing business indicators, as possible determinants of FDI inflows towards developing countries. The purpose of this section is to run some regression analysis to investigate the link between FDI and business friendliness of countries, after controlling for other factors which can also affect FDI decisions such as macroeconomic conditions and the quality of institutions or governance.

The regression specification is:

$$
\begin{aligned}
\left(\frac{F D I}{G D P}\right)_{i t}= & a_{0}+a_{1} \log \text { GDPPC }_{i t}+a_{2} \text { Inflation }_{i t}+a_{3} \text { Trade }_{i t} \\
& +a_{4} \text { Investment }_{\text {it }}+a_{5} \text { Corruption }_{i t} \\
& +a_{6} \text { Doing Business Indicator }_{i t}+\text { fixed effects } \\
& + \text { time effects }+\varepsilon_{i t}
\end{aligned}
$$

Where $\log$ GDPPC is the log of real GDP per capita; inflation is the inflation rate of consumer price index; Trade is exports plus imports in percent of GDP; Investment is gross fixed capital formation in percent of GDP; Corruption is the corruption index; Doing Business Indicator is one of the doing business indicators listed in Section 4. Fixed effects and time effects are included as well. $i$ stands for a country and $t$ stands for year.

The dependent variable is the ratio of net FDI inflows to GDP of a country. The definition of FDI inflows has been given in Section 2.

All the doing business indicators listed in Section 4 are included one by one in the regression specifications. Because of page limitations, we only included the statistically significant indicators while reporting the regression results. The expected signs which are reported in Table 2 are also the expected signs of the estimated coefficients of the doing business indicators.

The income level of a country can be important for foreign investors. It can give good information on domestic market conditions, as well as the quality of human capital. Thus, the expected sign of the estimated coefficient is positive. However, the graphical analysis in Section 3 does not support the existence of a strong correlation between FDI and real GDP per capita. Despite the fact that the simple relationship looks weak, it may change when we include it with other control variables in a regression specification. Real income is measured as the log of real GDP per capita in constant 2005 dollars.

The macroeconomic stability of countries is expected to be a strong determinant of FDI inflows. Foreign investors prefer politically and economically stable countries, especially for their long-term investments. We include the inflation rate of consumer price index to capture the impacts of macroeconomic stability. If inflation is high in any country, it means that investors may face many uncertainties. It will be hard to figure out their future returns from long-term 
investments such as FDI. Thus, we expect that higher inflation rates deter foreign investors. In this case, the estimated coefficient of inflation is going to be negative.

Trade openness of countries can give a good indication on how global the economy is. This is expected to be a very significant factor in determining FDI inflows. In open economies, foreign FDI investors can target both domestic and foreign markets. As a result, they can increase their market size. Countries with higher trade openness tend to have more open financial markets as well. Such reasons can make foreign investments more attractive in open economies. As a result, we expect to see a positive and statistically significant coefficient for trade openness. The trade openness indicator is defined as the sum of exports and imports of goods and services measured as a share of gross domestic product.

Domestic investment activities can give a good idea about the future performance of economies. Countries with higher investment and larger capital accumulation can grow faster. Their infrastructure capital is also expected to be in a higher quality. As a result, it is expected that countries with higher investment rates would be more attractive for foreign investors. Gross fixed capital formation in percent of GDP is used to capture domestic investment activities.

The quality of institutions is expected to impact investment decisions of foreign investors. In a country, a higher quality of institutions and governance indicates reliability and stability. In the analysis we use a corruption index taken from the ICRG Database to capture this concept. The assessment of corruption refers to the political system. The corruption index ranges from 1 to 6 . High points are given to low corruption countries and low points are given to high corruption countries. The sign of the estimated coefficient is expected to be positive.

The regression methodology is OLS for panel data. This way we can observe the changes over time and across countries. We include fixed effects to control for country differences and time effects to control for time differences. In the analysis we include the top 30 FDI recipient developing countries, as identified in Section 3, for the period of 2004 and 2013.

Table 4 reports the estimated coefficients of the regression specification given above. The estimated coefficients of the doing business indicators are reported in the last row of the table. It should be noted again that only statistically significant indicators are included in the table due to space limitations. The results show that two of the "starting a business" indicators have statistically significant and negative coefficients as expected. The higher the cost of "starting a business" and higher paid-in minimum capital to "start a business," the lower the FDI inflows. The economic significance of the variables is relatively low, but they are highly significant at the 1 percent level. The results show that firms prefer countries where it is easier to start a business.

One of the indicators for "dealing with construction permits", the cost in percent of income per capita, has a negative and statistically significant impact on FDI inflows, even after controlling for other variables which can also affect FDI inflows. However, the size of the coefficient is small. In a similar concept, the cost of "registering property" in percent of property value determines FDI inflows in a negative and significant way. The economic impact of the 
coefficient is high. These estimation results indicate that countries with lower costs of running a business can attract more FDI inflows into their countries.

The indicators of "protecting investors" have positive effects on FDI inflows. As expected, foreign investors transfer funds to countries in which their rights are protected better. The estimated coefficients of "extent of disclosure index" and "strength of investor protection index" are equal to 0.320 and 0.651 , respectively. They are also significant at the 5 percent level. These results indicate that as these two indicators improve by 1 point, we observe 0.320 and 0.651 percentage point improvements in the FDI inflows in percent of GDP. Such high coefficients clearly show that countries which do not sufficiently protect investors in general, cannot be attractive for foreign investors.

One interesting result is that the estimated coefficients of the cost to export and import are negative and statistically significant at the 10 percent level. Indeed, these are the expected impacts of the cost of trade on FDI inflows. Foreign investors are expected to prefer countries with lower trade costs because many of them transfer funds to foreign countries to open or run a business which has an international dimension. The result looks interesting because the simple correlation coefficient between the cost of trade indicators and FDI inflows were negative as reported in Section 4. When we control for other variables which can affect FDI inflows, including trade openness, the sign of the relationship between FDI inflows and the cost of trade becomes negative.

Closing a business can also have an important impact on FDI inflows. The higher the recovery rate after closing a business, the higher the FDI inflows are. Foreign investors consider "closing a business" indicators beforehand, while making their investment decisions. Just in case, they may want to be sure that they can recover some of the FDI funds that they invested in foreign countries.

Many control variables are statistically significant determinants of FDI inflows. The log of real GDP per capita has an expected positive sign and is mostly significant. It indicates that countries with higher growth rates can attract larger amounts of FDI inflows in percent of their GDP. Inflation has an expected negative and significant effect on FDI inflows. It means that foreign investors do not prefer high inflation countries, most likely due to their lower macroeconomic stability and higher uncertainty. The estimated coefficients of trade openness have the highest significance in the group. Open economies can attract more statistically significant FDI inflows into their countries. Similarly, gross domestic fixed capital formation has a positive and significant impact on FDI inflows. The corruption as one indicator of an institutional quality does not produce significant coefficients. The variable has the expected positive effect on FDI inflows, but the coefficients are mostly insignificant. This can be due to the fact that the variable for the level of income may already be capturing the possible effects of the quality of institutions. 
Table 4. Determinants of FDI Inflows in Developing Countries: “Doing Business" Indicators and Control Variables

\begin{tabular}{|c|c|c|c|c|c|c|c|c|c|}
\hline \multicolumn{10}{|l|}{ Dependent variable: FDI (\% of GDP) } \\
\hline $\begin{array}{ll}\text { Doing business } \\
\text { Indicators }\end{array}$ & $\begin{array}{l}\text { Starting a } \\
\text { business - } \\
\text { Paid-in Min. } \\
\text { Capital (\% of } \\
\text { income per } \\
\text { capita) }\end{array}$ & $\begin{array}{l}\text { Starting a } \\
\text { business - } \\
\text { Cost }(\% \text { of } \\
\text { income per } \\
\text { capita) }\end{array}$ & $\begin{array}{l}\text { Dealing with } \\
\text { Construction } \\
\text { Permits- Cost } \\
\text { (\% of income } \\
\text { per capita) }\end{array}$ & $\begin{array}{l}\text { Registering } \\
\text { Property- } \\
\text { Cost (\% of } \\
\text { property } \\
\text { value) }\end{array}$ & $\begin{array}{l}\text { Protecting } \\
\text { Investors- } \\
\text { Extent of } \\
\text { disclosure } \\
\text { index }(0-10)\end{array}$ & $\begin{array}{l}\text { Protecting } \\
\text { Investors- } \\
\text { Strength of } \\
\text { investor } \\
\text { protection } \\
\text { index }(0-10)\end{array}$ & $\begin{array}{l}\text { Cost to export } \\
\text { (US\$ per } \\
\text { container) }\end{array}$ & $\begin{array}{l}\text { Cost to import } \\
\text { (US\$ per } \\
\text { container) }\end{array}$ & $\begin{array}{l}\text { Resolving } \\
\text { Insolvency- } \\
\text { Recovery } \\
\text { rate (cents } \\
\text { on the } \\
\text { dollar) }\end{array}$ \\
\hline Constant & $\begin{array}{l}105.872 \\
(1.386)\end{array}$ & $\begin{array}{l}28.351 \\
(0.372)\end{array}$ & $\begin{array}{l}-518.15 \\
(-4.859)^{* * * *}\end{array}$ & $\begin{array}{l}-273.473 \\
(-3.377)^{* * * *}\end{array}$ & $\begin{array}{l}-425.156 \\
(-3.901)^{* * * *}\end{array}$ & $\begin{array}{l}-426.105 \\
(-3.95)^{* * * *}\end{array}$ & $\begin{array}{l}-447.605 \\
(-4.171)^{* * * *}\end{array}$ & $\begin{array}{l}-448.7 \\
(-4.189)^{* * * *}\end{array}$ & $\begin{array}{l}165.532 \\
(2.24)^{* *}\end{array}$ \\
\hline Log of real GDP & $\begin{array}{l}4.893 \\
(1.651)^{*}\end{array}$ & $\begin{array}{l}1.713 \\
(1.644)^{*}\end{array}$ & $\begin{array}{l}2.885 \\
(1.655)^{*}\end{array}$ & $\begin{array}{l}1.824 \\
(3.233)^{* * *}\end{array}$ & $\begin{array}{l}1.027 \\
(3.748) * * *\end{array}$ & $\begin{array}{l}1.701 \\
(3.78) * * *\end{array}$ & $\begin{array}{l}1.806 \\
(4.048)^{* * * *}\end{array}$ & $\begin{array}{l}1.812 \\
(4.068)^{* * * *}\end{array}$ & $\begin{array}{l}7.245 \\
(2.376)^{* * * *}\end{array}$ \\
\hline Inflation rate & $\begin{array}{l}-0.11 \\
(-2.141)^{* *}\end{array}$ & $\begin{array}{l}-0.037 \\
(-1.702)^{* *}\end{array}$ & $\begin{array}{l}-0.105 \\
(-1.639)^{*}\end{array}$ & $\begin{array}{l}-0.07 \\
(-1.705)^{*}\end{array}$ & $\begin{array}{l}-0.101 \\
(-1.843)^{* *}\end{array}$ & $\begin{array}{l}-0.093 \\
(-1.825)^{* *}\end{array}$ & $\begin{array}{l}-0.103 \\
(-1.764)^{* *}\end{array}$ & $\begin{array}{l}-0.103 \\
(-1.778)^{* *}\end{array}$ & $\begin{array}{l}-0.125 \\
(-2.417)^{* * * *}\end{array}$ \\
\hline Trade openness (\% of GDP) & $\begin{array}{l}0.031 \\
(1.709)^{*}\end{array}$ & $\begin{array}{l}0.042 \\
(1.675)^{*}\end{array}$ & $\begin{array}{l}0.152 \\
(5.275)^{* * *}\end{array}$ & $\begin{array}{l}0.102 \\
(4.005)^{* * *}\end{array}$ & $\begin{array}{l}0.138 \\
(4.65)^{* * *}\end{array}$ & $\begin{array}{l}0.138 \\
(4.674)^{* * * *}\end{array}$ & $\begin{array}{l}0.143 \\
(4.832)^{* * *}\end{array}$ & $\begin{array}{l}0.139 \\
(4.698) * * *\end{array}$ & $\begin{array}{l}0.029 \\
(1.716) * *\end{array}$ \\
\hline Gross fixed investment (\% of GDP) & $\begin{array}{l}0.565 \\
(9.387)^{* * * *}\end{array}$ & $\begin{array}{l}0.574 \\
(9.799)^{* * *}\end{array}$ & $\begin{array}{l}0.293 \\
(3.654)^{* * * *}\end{array}$ & $\begin{array}{l}0.367 \\
(5.585)^{* * *}\end{array}$ & $\begin{array}{l}0.304 \\
(3.673)^{* * *}\end{array}$ & $\begin{array}{l}0.302 \\
(3.667) * * *\end{array}$ & $\begin{array}{l}0.299 \\
(3.597)^{* * *}\end{array}$ & $\begin{array}{l}0.302 \\
(3.654)^{* * * *}\end{array}$ & $\begin{array}{l}0.577 \\
(9.265)^{* * * *}\end{array}$ \\
\hline Corruption index & $\begin{array}{l}0.163 \\
(0.249)\end{array}$ & $\begin{array}{l}0.239 \\
(0.377)\end{array}$ & $\begin{array}{l}0.142 \\
(0.189)\end{array}$ & $\begin{array}{l}0.128 \\
(0.193)\end{array}$ & $\begin{array}{l}0.069 \\
(0.09)\end{array}$ & $\begin{array}{l}0.092 \\
(0.12)\end{array}$ & $\begin{array}{l}0.105 \\
(0.136)\end{array}$ & $\begin{array}{l}0.057 \\
(0.074)\end{array}$ & $\begin{array}{l}0.231 \\
(0.351)\end{array}$ \\
\hline Doing Business Indicator & $\begin{array}{l}-0.004 \\
(-2.534)^{* * *}\end{array}$ & $\begin{array}{l}-0.018 \\
(-4.867)^{* * * *}\end{array}$ & $\begin{array}{l}-0.003 \\
(-3.387)^{* * * *}\end{array}$ & $\begin{array}{l}-0.245 \\
(-1.703)^{*}\end{array}$ & $\begin{array}{l}0.32 \\
(1.894)^{* *}\end{array}$ & $\begin{array}{l}0.651 \\
(1.84)^{* *}\end{array}$ & $\begin{array}{l}-0.001 \\
(-1.658)^{*}\end{array}$ & $\begin{array}{l}-0.001 \\
(-1.757)^{* *}\end{array}$ & $\begin{array}{l}0.1 \\
(1.753)^{* *}\end{array}$ \\
\hline Adjusted R2 & 0.604 & 0.625 & 0.698 & 0.674 & 0.683 & 0.685 & 0.682 & 0.683 & 0.598 \\
\hline Total no of observations & 361 & 361 & 269 & 314 & 269 & 269 & 269 & 269 & 360 \\
\hline Tests for normality & 1.456 & 1.287 & 1.092 & 1.338 & 1.478 & 1.133 & 1.254 & 0.955 & 1.056 \\
\hline Tests for heteroske. (White's test) & 0.821 & 0.972 & 0.772 & 0.812 & 1.134 & 0.942 & 0.559 & 1.072 & 1.038 \\
\hline Tests for autocorrelation & 1.721 & 1.834 & 1.785 & 2.075 & 1.873 & 1.996 & 2.387 & 2.109 & 1.846 \\
\hline
\end{tabular}

\section{Conclusion}

The findings of this paper indicate that the share of developing countries in FDI inflows has been increasing consistently, and dropping in developed countries. Many factors can play a role in the changing direction of funds. For example, differences in growth rates of developed and developing countries can be a good candidate, while explaining the changing direction of FDI inflows from developed to developing countries (developing countries are growing faster). In addition to such factors, the importance of the investment climate of countries cannot be ignored, especially while explaining long-term fund transfers such as FDI inflows. In this paper "doing business" indicators are used to capture the investment climate of countries. While these indicators are high and almost constant for developed countries, the values of the indicators are rapidly improving in developing countries. This means that developing countries are catching up to developed ones. The improvements are especially strong for "starting a business", "closing a business" and "protecting investors" indicators. As a result, it is expected that the improvements in "doing business" indicators can be important factors in attracting more FDI inflows towards developing countries.

The empirical results indeed show that countries with a better record of "doing business" indicators can attract more long-term foreign investment. The improvements in "ease of doing business" in developing countries have a statistically significant explanatory power in determining FDI inflows, even after controlling for other factors which may affect FDI inflows. With improving business friendliness of developing countries, their share in FDI inflows has been increasing consistently. Given that FDI inflows are the preferred type of foreign funds due to their longer terms, the main policy implication of the paper is that improving investment 
climates is essential to attract more FDI inflows to developing countries.

\section{Acknowledgement}

I would like to thank Theodora Avramidis for her excellent research assistance.

\section{References}

Adams, Samuel. (2009). Foreign Direct investment, domestic investment, and economic growth in Sub-Saharan Africa. Journal of Policy Modeling. 31(2009). 939-949. http://dx.doi.org/10.1016/j.jpolmod.2009.03.003

Alfaro, L., Areendam C., Sebnem K., \& Sayek, S. (2010). Does foreign investment promote growth? Exploring the role of financial markets on linkages. Journal of Development Economics. 91. 242-256. http://dx.doi.org/10.1016/j.jdeveco.2009.09.004

Alfaro, L., \& Chen, M. (2010). Surviving the Global Financial Crisis: Foreign Direct Investment and Establishment Performance. Harvard Business School Working Paper No: 10-110 (June 2010).

Alfaro, L., Anusha C., \& Kanczuk, F. (2014). The Real Effects of Capital Controls: Credit Constraints, Exporters and Firm Investment. NBER Working Paper. NBER Reporter 2014 Number 2: Conferences (June).

An, Z. (2012). Taxation and foreign direct investment (FDI): empirical evidence from a quasi-experiment in China. International Tax and Public Finance. 19(5). 660-676. http://dx.doi.org/10.1007/s10797-011-9201-0

Baliamoune-Lutz, M. (2004). Does FDI contribute to economic growth?. Business Economics. 39(2). 49-56.

Blanchard, O., Dell' Ariccia, G., \& Mauro, P. (2010). Rethinking Macroeconomic Policy. Journal of Money, Credit, and Banking. 42(1). 200-15.

Blanchard, O., Ostry, J., Gosh, A., \& Chamon, M. (2014). Managing Capital Flows: How to Combine Capital Controls, Macro Prudential Tools, Foreign Exchange intervention, and the Policy Rate. IMF Working Paper (June).

Blonigen, B. A., \& Piger, J. (2011). Determinants of Foreign Direct Investment. NBER Working Paper No: 16704.

Borensztein, E., De Gregorio, J., \& Lee, J-W. (1995). How does foreign investment affect economic growth?, NBER Working Paper Series No. 5057, National Bureau of Economic Research.

Botero, J., Djankov, S., La Porter, R., Lopes-De-Silanes, F., \& Shleifer, A. (2004). The regulation of labor. Quarterly Journal of Economics. 119(4). 1339-82. http://dx.doi.org/10.1162/0033553042476215

Davis, S., \& Presno, I. (2014). Capital Controls as an Instrument of Monetary Policy. Federal Reserve Bank of Dallas, Globalization and Monetary Policy Institute, Working Paper No. 171 
(June).

De Gregorio, J. (1992), Economic growth in Latin America. Journal of Development Economics. 39(1). 59-84. http://dx.doi.org/10.1016/0304-3878(92)90057-G

Debaera, P., Lee, H., \& Lee, J. (2010). It matters where you go: Outward foreign direct investment and multinational employment growth at home. Journal of Development Economics. 91. 301-309. http://dx.doi.org/10.1016/j.jdeveco.2009.07.002

Djankov, S., La Porter, R., Lopes-De-Silanes, F. \& Shleifer, A. (2002). The regulation of entry. Quarterly Journal of $\quad$ Economics. $117(1) . \quad 1-37$. http://dx.doi.org/10.1162/003355302753399436

Djankov, S., La Porter, R., Lopes-De-Silanes, F., \& Scheifler, A. (2003). The new comparative economics. Journal of Comparative Economics. 31(4). 595-619. http://dx.doi.org/10.1016/j.jce.2003.08.005

Djankov, S., McLiesh, C. \& Shleifer, A. (2007). Private credit in 129 countries. Journal of Financial Economics. 84(2). 299-329. http://dx.doi.org/10.1016/j.jfineco.2006.03.004

Dollar, D., Hallward-Driemeier, M., \& Mengistae, T. (2006). Investment climate and international integration. World Development. 39(9). 1498-1516. http://dx.doi.org/10.1016/j.worlddev.2006.05.001

Economist, The. (2011). Foreign Direct Investment. Jan 20th 2011.

Harris, C. (2003). Private participation in infrastructure in developing countries: trends, impacts, and policy lessons. The World Bank Working Paper 5, The World Bank, Washington, DC, April.

Hattari, R., \& Rajan, R. S. (2010). India as a source of outward foreign direct investment. Oxford Development Studies. $38(4)$ (December). http://dx.doi.org/10.1080/13600818.2010.524695

Herzer, Dierk. (2011). The Long-run Relationship between Outward Foreign Direct Investment and Total Factor Productivity: Evidence for Developing Countries. Journal of $\begin{array}{lllll}\text { Development } & \text { Studies. } & 47(5) . & 767-785 . & \text { May }\end{array}$ http://dx.doi.org/10.1080/00220388.2010.509790

Independent Panel. (2013). Independent Panel Review of the Doing Business Report (June 2013). World Bank: Washington D.C. [http://www.dbrpanel.org/sites/dbrpanel/files/doing-business-review-panel-report.pdf]

International Monetary Fund. (1993). Balance of Payments Manual. 5th edition. Washington DC.

Kemme, D. M., Nikolsko - Rzhevskyy, A., \& Mukherjee, D. (2014). Foreign Capital, Spillovers and Export Performance in Emerging Economies: Evidence from Indian IT Firms. Review of Development Economics. 11/2014, 18(4). 681-92. 
Kinda, T. (2009), Investment climate and FDI in developing countries: Firm-level evidence. World Development. 38(4). 498-513. http://dx.doi.org/10.1016/j.worlddev.2009.12.001

Kinoshita, Yuko. (2012). Foreign Direct Investment and the Crisis: Is This Time Different?. IMF Research Bulletin. 13(1). (March 2012).

Magud, N., Reinhart, C., \& Rogoff, K. (2011). Capital Controls: Myth and Reality - A Portfolio Balance Approach. NBER Working Paper No. 16805.

Medina, J.P., \& Roldos, J. (2014). Monetary and Macroprudential Policies to Manage Capital Flows. IMF Working Paper No: WP/14/30 (February).

Morris, R., \& Aziz, A. (2011). Ease of Doing Business and FDI Inflow to Sub-Sharan Africa and Asian Countries. Cross Cultural Management: An international Journal. 18(4). 400-411.

Mottaleb, K. A., \& Kalirajan, K. (2010). Determinants of foreign direct investment in developing countries: A comparative analysis. The Journal of Applied Economic Research. 4(4). 369-404.

Nnadozie, E., \& Njuguna, A. E. (2011). Investment Climate and Foreign Direct Investment in Africa. the $6^{\text {th }}$ African Economic Conference in Addis Ababa, Ethiopia on 26-28 October 2011.

Olivia, M. A., \& Rivera-Batiz, L. A. (2002). Political institutions, capital flows, developing country growth: an empirical investigation. Review of Development Economics. 6(2). 248-62. http://dx.doi.org/10.1111/1467-9361.00152

Ostry, J. D., Ghosh, A., Habermeier, K., Chamon, M., Qureshi, M. S., \& Reinhardt, D. B. S. (2010). Capital Inflows: The Role of Controls. IMF Staff Position Note 10/04 (Washington: International Monetary Fund).

Ostry, J. D., Ghosh, A. R., Chamon, M., \& Qureshi, M. S. (2011). Capital Controls: When and Why?. IMF Economic Review. 59. August, 562-580.

Piwonski, Katherine. (2010). Does the 'Ease of Doing Business' In a Country Influence its Foreign Direct Investment Inflows?. unpublished paper. Bryant University (April 2010).

Resminia, L., \& Siedschlag, I. (2013). Is foreign direct investment to China crowding out the foreign direct investment to other countries?. China Economic Review. 25. June, 1-16. http://dx.doi.org/10.1016/j.chieco.2012.12.003

Sekkat, K., \& Veganzones-Varoudakis, M-A. (2007). Openness, investment climate, and FDI in developing countries. Review of Development Economics. 11(4). 607-620. http://dx.doi.org/10.1111/j.1467-9361.2007.00426.x

Tran, T. Q. (2008). Reforms in FDI policy and the investment climate in Vietnam. Journal of World Trade. 42(6). 1179-1202.

United Nations Conference on Trade and Development. (2009). Assessing the impact of the current financial and economic crisis on global FDI flows. (April).

Voss, H., Fetscherin, M., \& Gugler, P. (2010). 30 Years of foreign direct investment to China: 


\section{Macrothink}

Business and Economic Research

ISSN 2162-4860 2015, Vol. 5, No. 1

An interdisciplinary literature review. International Business Review. 19(3). 235-246.

\section{Copyright Disclaimer}

Copyright for this article is retained by the author(s), with first publication rights granted to the journal.

This is an open-access article distributed under the terms and conditions of the Creative Commons Attribution license (http://creativecommons.org/licenses/by/3.0/). 